\title{
Management of Residual Cardiovascular Risk in Dyslipidaemic Patient with Metabolic Syndrome
}

\section{Danish Mahmood*}

Department of Pharmacology \& Toxicology, Qassim University, Al-Qassim, Saudi Arabia

*Corresponding author: Danish Mahmood, Unaizah College of Pharmacy, Department of Pharmacology \& Toxicology, Qassim University, Al-Qassim, Saudi Arabia, Tel: +966-594016751; E-mail: ma.alam@qu.edu.sa

Rec date: Dec 31, 2014 Acc date: Feb 10, 2015 Pub date: Feb 15, 2015

Copyright: ( 2015 Mahmood D. This is an open-access article distributed under the terms of the Creative Commons Attribution License, which permits unrestricted use, distribution, and reproduction in any medium, provided the original author and source are credited.

\begin{abstract}
Metabolic syndrome (MS) is a clustering of metabolic and underlying risk factors which doubles the risk of atherosclerotic cardiovascular disease. It is more prevalent in some ethnic groups, especially in the Asian world.

Global urbanization and sedentary life habits have increased the underlying risk factors characterised by physical inactivity, atherogenic diet and obesity. Therefore, its detection, prevention, and treatment serve as an important approach for the reduction of cardiovascular risk in the general population and strictly emphasized on strict therapeutic lifestyle changes.

In our case report, we present effective management of a dyslipidaemic patient with MS by medication. However, her underlying risk factors were not controlled due to her inability to strictly adopt therapeutic lifestyle changes.
\end{abstract}

\section{Introduction}

Metabolic syndrome (MS) or Syndrome $\mathrm{X}$ is a clustering of metabolic and underlying risk factors which doubles the risk of atherosclerotic cardiovascular disease (CVD). The metabolic risk factors include atherogenic dyslipidemia (elevated triglycerides [TG], small-dense low density lipoprotein [LDL] and low high-density lipoproteins [HDL]), elevated blood pressure (BP) and fasting plasma glucose (FPG), and prothrombotic and proinflammatory states [1]. Underlying risk factors for MS include physical inactivity, atherogenic diet, abdominal or upper body obesity, measured by waist circumference, insulin resistance, characterized by impaired FPG. The other major risk factors include cigarette smoking, family history of premature coronary heart disease (CHD), and aging.

We present a case report of management of residual CVD risk in a female dyslipidaemic patient with MS.

\section{Case Report}

A 62-year old Mexican American woman went to a routine clinical visit. Her body mass index (BMI), waist circumference, FPG, and BP were $31.2 \mathrm{~kg} / \mathrm{m}^{2}, 36$ inches, $115 \mathrm{mg} / \mathrm{dL}$ and $136 / 77 \mathrm{~mm} \mathrm{Hg}$, respectively. She was already on angiotensin-converting enzyme (ACE) inhibitor, the antihypertensive medication, which helped to reduce her BP. Her lipid profile revealed borderline elevation of various lipid parameters, including total cholesterol $(227 \mathrm{mg} / \mathrm{dL})$, LDL-C (130 mg/dL), HDL-C (40 mg/dL), TG $(285 \mathrm{mg} / \mathrm{dL})$, and nonHDL-C $(187 \mathrm{mg} / \mathrm{dL})$. Her clinician diagnosed her with impaired fasting glucose and MS and reported her Framingham risk score of $12 \%$. He prescribed atorvastatin $(10 \mathrm{mg} /$ day $)$ and suggested to adopt therapeutic lifestyle changes (diet, exercise) and stop smoking.

During her follow up visit after 3 months (Visit 1), she reported that her smoking habits were reduced from 1 pack to half pack a day.
However, there was no change in her BMI $\left(31.8 \mathrm{~kg} / \mathrm{m}^{2}\right)$ and waist circumference (36.5 inches). Her BP was slightly raised (from 136/77 $\mathrm{mm} \mathrm{Hg}$ to $138 / 80 \mathrm{~mm} \mathrm{Hg}$ ). To normalize her BP, the clinician prescribed amlodipine, a calcium channel blocker, in addition to existing ACE inhibitor. After the use of atrovastatin a change in her lipid profile was observed. Her total cholesterol, LDL-C, non-HDL-C, and TG were reduced from 227 to $181 \mathrm{mg} / \mathrm{dL} ; 130$ to $89 \mathrm{mg} / \mathrm{dL} ; 187$ to $139 \mathrm{mg} / \mathrm{dL}$, and $285 \mathrm{mg} / \mathrm{dL}$ to $248 \mathrm{mg} / \mathrm{dL}$, respectively and HDL-C levels were increased from 40 to $42 \mathrm{mg} / \mathrm{dL}$. She reached her target goal of LDL-C $(<100 \mathrm{mg} / \mathrm{dL})$ but did not reach target goal of non-HDL-C $(<130 \mathrm{mg} / \mathrm{dL})$ as per ATP III guidelines (Table 1). Though there was an overall improvement in the metabolic parameters, her FPG was elevated $(132 \mathrm{mg} / \mathrm{dL})$ and was diagnosed with type 2 diabetes. The clinician prescribed metformin (500 $\mathrm{mg}$, twice a day) to reduce her FPG levels and added fenofibrate ( $145 \mathrm{mg} /$ day) to existing atorvastatin therapy to further elevate HDL-C and lower TG levels. He explained the importance of lifestyle changes and again stressed her to strictly adopt lifestyle changes.

\begin{tabular}{|l|l|l|l|}
\hline $\begin{array}{l}\text { Risk } \\
\text { categories }\end{array}$ & Criteria & LDL goal & $\begin{array}{l}\text { Non-HDL } \\
\text { goal }\end{array}$ \\
\hline High risk & $\begin{array}{l}\text { 10-year risk for CHD }>20 \% \text { or } \\
\text { CHD risk equivalent, including } \\
\text { diabetes }\end{array}$ & $\begin{array}{l}<100 \mathrm{mg} / \mathrm{dL}(2.6 \\
\mathrm{mmol} / \mathrm{L})\end{array}$ & $\begin{array}{l}<130 \mathrm{mg} / \mathrm{dL} \\
(3.3 \mathrm{mmol} / \mathrm{L})\end{array}$ \\
\hline Moderate & $\begin{array}{l}2 \text { or more risk factors and 10- } \\
\text { year risk for CHD }<20 \%\end{array}$ & $\begin{array}{l}<130 \mathrm{mg} / \mathrm{dL}(3.3 \\
\mathrm{mmol} / \mathrm{L})\end{array}$ & $\begin{array}{l}<160 \mathrm{mg} / \mathrm{dL} \\
(4.1 \mathrm{mmol} / \\
\mathrm{L})\end{array}$ \\
\hline Low & $\begin{array}{l}1 \text { major risk factor and 10-year } \\
\text { risk for CHD }<10 \%\end{array}$ & $\begin{array}{l}<160 \mathrm{mg} / \mathrm{dL}(4.1 \\
\mathrm{mmol} / \mathrm{L})\end{array}$ & $\begin{array}{l}<190 \mathrm{mg} / \mathrm{dL} \\
(4.9 \mathrm{mmol} / \mathrm{L})\end{array}$ \\
\hline
\end{tabular}

Table 1: NCEP ATP-III comparison of LDL-C and non-HDL-C target goal [9]. LDL-C: low-density lipoprotein cholesterol; HDL-C: high 
density lipoprotein cholesterol; NCEP ATP-III: National Cholesterol Education Program Adult Treatment Panel-III

Three months after Visit-1, no change in BMI and waist circumference was observed in spite of her reduced smoking habit. The combination of amlodipine plus ACE inhibitor normalised her BP (from 138/80 $\mathrm{mm} \mathrm{Hg}$ to $122 / 74 \mathrm{~mm} \mathrm{Hg}$ ) and metformin reduced her FPG (from $132 \mathrm{mg} / \mathrm{dL}$ to $114 \mathrm{mg} / \mathrm{dL}$ ). After treatment with fenofibrate and atorvastatin her lipid profile was further improved. Her total cholesterol, LDL-C, non-HDL-C, and TG reduced to $158 \mathrm{mg} / \mathrm{dL}, 80$ $\mathrm{mg} / \mathrm{dL}, 110 \mathrm{mg} / \mathrm{dL}$, and $148 \mathrm{mg} / \mathrm{dL}$, respectively, and her HDL-C increased to $48 \mathrm{mg} / \mathrm{dL}$. Since she did not experience any adverse muscle, liver, or kidney events, the treatment was continued. The medications helped her lower presence of most of her metabolic and major risk factors. However, no changes in underlying risk factors were observed owing to her inability to adopt to a strict lifestyle changes.

\section{Discussion}

The two most widely accepted criteria for the diagnosis of MS in the United States have been proposed by the National Cholesterol Education Program Adult Treatment Panel (NCEP ATP III) and the American Heart Association/National Heart, Lung, and Blood Institute (AHA/NHLBI). International Diabetes Federation (IDF) was similar to NCEP ATP III and AHA/NHLBI criteria Except that it included central obesity plus two or more than two criteria (Table 2) [2]. Enlarged waist plus elevated triglycerides serves as a stronger predictor of cardiovascular mortality and all-cause mortality after adjustment of age, smoking status, and LDL-C levels [1,3]. In our report, the patient was a 62-year old female of Mexican American descent with enlarged waist (36 inches) and borderline elevation of lipid parameters with elevated TG levels $(285 \mathrm{mg} / \mathrm{dL})$, and had diagnosis of MS. Our results corroborated with earlier reports where females aged $>60$ years, enlarged waist, elevated TG and the Mexican American descent have higher predisposition to MS. Lifestyle modifications have been reported to be effective in resolving metabolic syndrome and reducing the severity of related abnormalities (fasting blood glucose, waist circumference, systolic and diastolic blood pressure, and triglycerides) in people with metabolic syndrome. Hence doctor advised her therapeutic lifestyle changes in addition to medications for her problem. She was asked to do a routine physical activity for 30-60 minutes daily of moderate-intensity aerobic activity plus an increase in daily lifestyle activities. Secondly, she was told to reduce her weight as it is important for those with abdominal obesity and MS. Lastly, she was asked to modify her diet composition which should include fresh fruit and vegetables, wholegrain or high-fiber, reduction in fat intake, diet rich in mono-unsaturated fats (eg, olive oil), omega-3 polyunsaturated fatty acids (PUFAs), and complex carbohydrate to form the major portion of calories. Other lifestyle suggested modifications were quit smoking cessation and avoid excessive alcohol intake. It has been reported that lifestyle factors potently determine both physical and mental health. In modern affluent societies, the diseases inflicting the greatest mortality and morbidity such as CVD, obesity, diabetes, and cancer are now said to be strongly determined by lifestyle. It has been reported that differences in just four lifestyle factors which include smoking, physical activity, alcohol intake, and diet could exert a major impact on mortality, and even small differences in lifestyle could make a major difference in health status. Consequently, there is growing awareness that contemporary medicine needs to focus on lifestyle changes for primary prevention, for secondary intervention, and to empower patients' self-management of their own health [4].

\begin{tabular}{|c|c|c|}
\hline NCEP III & NHLBI/AHA Criteria & IDF Criteria \\
\hline & Any 3 or more criteria & $\begin{array}{l}\text { Central obesity + any } 2 \\
\text { or more criteria }\end{array}$ \\
\hline $\begin{array}{l}\text { Waist } \\
\text { circumference: } \\
\text { men } \geq 102 \mathrm{~cm} \text { ( } 40 \\
\text { in); } \\
\text { women } \geq 35 \text { in ( } 88 \\
\mathrm{~cm} \text { ) }\end{array}$ & $\begin{array}{l}\text { Waist circumference: men } \geq 102 \\
\mathrm{~cm} \text { ( } \geq 40 \text { inches); women } \geq 88 \\
\mathrm{~cm} \quad(\geq 35 \text { inches); lower cut- } \\
\text { points for insulin-resistant } \\
\text { individuals }\end{array}$ & $\begin{array}{l}\text { Waist circumference } \\
\text { ethnicity specific }\end{array}$ \\
\hline $\begin{array}{l}\mathrm{TG} \geq 150 \mathrm{mg} / \mathrm{dL} \\
(1.7 \\
\mathrm{mmol} / \mathrm{L})\end{array}$ & $\begin{array}{l}\mathrm{TG}>150 \mathrm{mg} / \mathrm{dL}(1.7 \mathrm{mmol} / \mathrm{L}) \text { or } \\
\text { on specific treatment }\end{array}$ & $\begin{array}{l}\mathrm{TG}>150 \mathrm{mg} / \mathrm{dL} \quad(1.7 \\
\mathrm{mmol} / \mathrm{L}) \text { or on specific } \\
\text { treatment }\end{array}$ \\
\hline $\begin{array}{l}\mathrm{HDL}-\mathrm{C}: \\
\mathrm{men}<40 \mathrm{mg} / \mathrm{dL} \\
(1.03 \mathrm{mmol} / \mathrm{L}) \\
\text { Women }<50 \mathrm{mg} / \mathrm{dL} \\
(1.3 \mathrm{mmol} / \mathrm{L})\end{array}$ & $\begin{array}{l}\mathrm{HDL}-\mathrm{C}: \text { men<40 } \mathrm{mg} / \mathrm{dL} \quad(1.03 \\
\mathrm{mmol} / \mathrm{L}) ; \text { women }<50 \mathrm{mg} / \mathrm{dL} \\
(1.29 \mathrm{mmol} / \mathrm{L})\end{array}$ & $\begin{array}{l}\text { HDL-C: } \text { men }<40 \mathrm{mg} / \mathrm{dL} \\
(1.03 \quad \mathrm{mmol} / \mathrm{L}) \\
\text { women }<50 \mathrm{mg} / \mathrm{dL}(1.29 \\
\mathrm{mmol} / \mathrm{L}) \text { or on specific } \\
\text { treatment }\end{array}$ \\
\hline $\begin{array}{l}\mathrm{SBP} \geq 130 \mathrm{~mm} \mathrm{Hg} \\
\text { or } \mathrm{DBP} \geq 85 \mathrm{~mm} \mathrm{Hg}\end{array}$ & $\begin{array}{l}\mathrm{SBP} \geq 130 \mathrm{~mm} \mathrm{Hg} \text { or } \mathrm{DBP} \geq 85 \\
\mathrm{~mm} \mathrm{Hg} \text { or antihypertensive } \\
\text { medication }\end{array}$ & $\begin{array}{l}\mathrm{SBP} \geq 130 \mathrm{~mm} \mathrm{Hg} \text { or } \\
\mathrm{DBP} \geq 85 \mathrm{~mm} \mathrm{Hg} \text { or } \\
\text { antihypertensive } \\
\text { medication }\end{array}$ \\
\hline $\mathrm{FBG} \geq 110 \mathrm{mg} / \mathrm{dL}$ & $\begin{array}{l}\mathrm{FBG} \geq 100 \mathrm{mg} / \mathrm{dL}(5.6 \mathrm{mmol} / \mathrm{L}) \text { or } \\
\text { on drug treatment for elevated } \\
\text { glucose }\end{array}$ & $\begin{array}{l}\mathrm{FBG} \geq 100 \mathrm{mg} / \mathrm{dL} \quad(5.6 \\
\mathrm{mmol} / \mathrm{L}) \text { or previously } \\
\text { diagnosed type } 2 \mathrm{DM}\end{array}$ \\
\hline
\end{tabular}

Table 2: NHLBI/AHA and IDF Diagnostic Criteria for Metabolic Syndrome $[1,2]$. DBP = diastolic blood pressure; FBG = fasting blood glucose; HDL-C = high-density lipoprotein cholesterol; IDF: International Diabetes Federation; NHLBI/AHA: National Heart Lung Blood Institute/American Heart Association; SBP = systolic blood pressure; $\mathrm{TG}=$ triglyceride

Non-HDL-C reported as a stronger predictor of CVD risk than LDL-C and was considered as a secondary target after attainment of LDL-C goal with TGs $\geq 200 \mathrm{mg} / \mathrm{dL}$ (5.17 mmol/L) [1,5-8]. During her follow up visit her LDL-C, total cholesterol, TG got reduced by $31.5 \%$, $20.2 \%$, and $13 \%$, respectively, and HDL-C goal was elevated by $5 \%$ after the use of atorvastatin (10 $\mathrm{mg} /$ day). Our results were in agreement with the previous study where standard doses of statins (simvastatin 10-40 $\mathrm{mg} /$ day, pravastatin $40 \mathrm{mg}$ /day and lovastatin $20-40 \mathrm{mg} /$ day) reduced total cholesterol by $18-26 \%$, LDL-C by $25-30 \%$ and TG by $11-17 \%$, and increased HDL-C by $5-7 \%$ [7]. However, other studies reported statins to be inadequate in the residual CVD risk associated with lipid abnormalities, especially above TG>220 mg/dL [8-10]. As per NCEP ATP III guidelines, statins or TG lowering drugs, such as fibrates or niacin served a vital role in achieving non HDL-C and LDL-C goals where the non-HDL-C goal was always $30 \mathrm{mg} / \mathrm{dL}$ higher than the LDL-C goal [11]. In our report too, we observed that the patient after treatment with fenofibrate and atorvastatin achieved the largest goal of LDL-C and non-HDL-C. The NCEP ATP III and the AHA/NHLBI recognized HDL-C as a tertiary target but did not set an HDL-C goal level. These two organisations including ADA advocated the use of fibrates to reduce TG and elevate HDL-C in patients with the MS or diabetes and suggested that fenofibrate combination with statin may be an effective and safer alternative than statin alone. In 2010, in a review, fenofibrate is of benefit in the 
Citation: Mahmood D (2015) Management of Residual Cardiovascular Risk in Dyslipidaemic Patient with Metabolic Syndrome. General Med 3: 1000163. doi:10.4172/2327-5146.1000163

Page 3 of 3

treatment of dyslipidemia, especially among those with MS [12]. Another study, the same year, reported that both atorvastatin and fenofibrate exhibited multidirectional pleiotropic effects in subjects with MS [13]. Though, the ACCORD trial did not support routine use of combination therapy with fenofibrate and simvastatin [14] to reduce cardiovascular risk in the majority of high-risk type 2 diabetic patients, but we had prescribed atorvastatin that the patient was responding well. Furthermore, we also observed that the patient did not experience any side-effects with the combination therapy of atorvastatin and fenofibrate and hence prescribed to continue her treatment.

In conclusion, the metabolic risk factors for MS in dyslipidaemics can be well managed by appropriate treatment but the underlying risk factors could only be managed by adopting strict therapeutic life style changes.

\section{References}

1. Grundy SM, Cleeman JI, Daniels SR, Donato KA, Eckel RH, et al. (2005) Diagnosis and management of the metabolic syndrome: an American Heart Association/National Heart, Lung, and Blood Institute Scientific Statement. Circulation 112: 2735-2752.

2. International Diabetes Foundation. The IDF consensus worldwide definition of the metabolic syndrome.

3. Tankó LB, Bagger YZ, Qin G, Alexandersen P, Larsen PJ (2005) Enlarged waist combined with elevated triglycerides is a strong predictor of accelerated atherogenesis and related cardiovascular mortality in postmenopausal women. Circulation 111: 1883-1890.

4. Walsh R (2011) Lifestyle and Mental Health. Amer Psychol 66: 579-592.

5. Cui Y, Blumenthal RS, Flaws JA, Whiteman MK, Langenberg P, et al. (2001) Non-high-density lipoprotein cholesterol level as a predictor of cardiovascular disease mortality. Arch Intern Med 161: 1413-1419
6. Ridker PM, Rifai N, Cook NR, Bradwin G, Buring JE (2005) Non-HDL cholesterol, apolipoproteins A-I and B100, standard lipid measures, lipid ratios, and CRP as risk factors for cardiovascular disease in women. JAMA 294: 326-333.

7. LaRosa JC, Grundy SM, Waters DD, Shear C, Barter P, Fruchart JC, et al. (2005) for the Treating to New Targets (TNT) Investigators. Intensive lipid lowering with atorvastatin in patients with stable coronary disease. N Engl J Med 352: 1425-1435.

8. Mathers CD, Loncar D (2006) Projections of global mortality and burden of disease from 2002 to 2030. PLoS Med 3: 2011-2030.

9. Heart Protection Study Collaborative Group (2012) MRC/BHF Heart Protection Study of cholesterol lowering with simvastatin in 20,536 highrisk individuals: a randomised placebo-controlled trial. Lancet 360: 7-22.

10. National Cholesterol Education Program (NCEP) Expert Panel (2002) Detection, Evaluation, and Treatment of High Blood Cholesterol in Adults (Adult Treatment Panel III). Third Report of the National Cholesterol Education Program (NCEP) Expert Panel on Detection, Evaluation, and Treatment of High Blood Cholesterol in Adults (Adult Treatment Panel III) final report. Circulation 106: 3143-3421.

11. Grundy SM, Cleeman JI, Merz BN, Brewer HB, Clark LTJ, et al. (2004) Implications of recent clinical trials for the national cholesterol education program adult treatment panel III guidelines. Circulation 110:227-239.

12. Kraja AT, Province MA, Straka RJ, Ordovas JM, Borecki IB, et al. (2010) Fenofibrate and metabolic syndrome. Endocr Metab Immune Disord Drug Targets 10: 138-48.

13. Krysiak R, Gdula-Dymek A, Bachowski R, Okopien B (2010) Pleiotropic effects of atorvastatin and fenofibrate in metabolic syndrome and different types of pre-diabetes. Diabetes Care 33: 2266-2270.

14. The ACCORD Study Group (2010) Effects of Combination Lipid Therapy in Type 2 Diabetes Mellitus. N Engl J Med 362: 1563-1574 